\title{
15. Space Bitches, Witches, and Kick-Ass Princesses
}

\author{
Star Wars and Popular Feminism
}

Megen de Bruin-Molé

Since its acquisition by Disney in 2012, the Star Wars franchise has been widely praised for its feminism. New heroes such as Jyn Erso and Rey have been hailed as feminist triumphs for Star Wars and mainstream entertainment more broadly. New characters aimed at a new generation of fans, like Rebels's pink-clad fighter-cum-artist Sabine Wren, and new novels devoted to characters like Leia Organa and Ahsoka Tano (from The Clone Wars), ${ }^{1}$ are often cited as part of a growing commitment to female characters and to feminism by association. Likewise, the marketing force of Star Wars can now be felt strongly in female-targeted sectors (makeup, fashion, dolls). ${ }^{2}$ Does all of this mean, as one reviewer put it, that Star Wars "finally awakens to a feminist world"? ${ }^{3}$

Such assertions have rubbed some fans the wrong way — after all, women have made up a significant and vocal portion of the Star Wars fanbase from the beginning. ${ }^{4}$ As one fan commented, "I'm sure that people went 'Wow!' when they saw the first female Jedi in the prequels. The fanfic of the $1970 \mathrm{~s}$ had women Jedi all the time and women smugglers. Nothing new there for the older fans." ${ }^{\prime 5}$ Will Brooker has also argued that the original female fans made the franchise their own through grassroots community-building,

1 Claudia Gray, Bloodline (London: Random House, 2016); E. K. Johnston, Ahsoka (Glendale, CA: Disney Book Group, 2016).

2 Lisa Richwine, "Disney's 'Star Wars' Marketing Force Reaches for Female Fans," Reuters, December 15, 2015, http://uk.reuters.com/article/us-film-starwars-women -analysis-idUKKBNoTX1J720151215.

3 Michael Roddy, "Star Wars: The Force Finally Awakens to a Feminist World," DNA India, December 16, 2015, http://www.dnaindia.com/entertainment/report-star-wars-the-force-finally -awakens-to-a-feminist-world-2156317.

4 As one famous Star Wars fanzine essay asks, "If there are men in media fandom, they're certainly very quiet. To turn about a feminist phrase then, why is half the human race so poorly represented in Star Wars and other media fandoms?" Pat Nussman, "Where the Boys Are," in Alderaan: The Star Wars Letterzine, vol. 15 (Toledo, OH: Kzinti Press, 1981), 2.

5 Tish Wells, private email correspondence, November 14, 2016. 
crafting, and fan fiction. ${ }^{6}$ In other words, their fandom is built on free engagement with the storyworld and many do not feel a strong need to be validated or greeted as consumers of licensed merchandise. ${ }^{7}$ Fan activity, of course, is not franchise-sanctioned and the kinds of stories that are licensed can certainly have a significant impact on a storyworld's feminist potential. While Leia's example is a powerful one, and although there are certainly more female role models in the franchise now than there were in 1977, can we call the Star Wars franchise feminist?

Broadly speaking, feminists believe in and advocate for social and political gender equality, but, as Mary Hawkesworth points out, feminism is "a collective noun" with many interpretations and aims. ${ }^{8}$ Rather than trying to condense a rich discussion of feminism in Star Wars into just a handful of pages, in this chapter I offer a few examples from very different corners of the Star Wars storyworld. They illustrate some of the diverse "interpretations and aims" of feminist discourse that are created by the complex interplay between fans and the multi-authored, media-industrial Star Wars franchise. ${ }^{9}$ First, I look at discourses of feminism and the representation of women in Star Wars, paying special attention to the stories outside of the films. Then, I explore the way the storyworld's non-narrative paratexts—-toys, clothes, and merchandising — have impacted its engagement with feminist discourse. Finally, I look at some of the ways in which fans and storytellers have politicized Star Wars, and what this may tell us about the future of the franchise. These examples provide a brief but informative glimpse at the history of Star Wars's engagement with feminist discourse.

6 Will Brooker, Using the Force: Creativity, Community and Star Wars Fans (New York: Continuum, 2002), 199-220.

7 Jonathan Gray, Show Sold Separately: Promos, Spoilers, and Other Media Paratexts (New York University Press, 2010), 17.

8 Mary E. Hawkesworth, Globalization and Feminist Activism (Oxford: Rowman \& Littlefield, 2006), 25 .

9 For other studies of feminist discourse and Star Wars, see Brooker, Using the Force, 129-71, 199-220; Henry Jenkins, “Quentin Tarantino's Star Wars? Digital Cinema, Media Convergence, and Participatory Culture," in Rethinking Media Change: The Aesthetics of Transition, ed. David Thorburn and Jenkins (Cambridge, MA: MIT Press, 2003), 549-576; Diana Dominguez, "Feminism and the Force: Empowerment and Disillusionment in a Galaxy Far, Far Away," in Culture, Identities, and Technology in the Star Wars Films, ed. Carl Silvio and Tony M Vinci (Jefferson, NC: McFarland, 2007), 109-133; Gray, Show Sold Separately, 177-87; Derek Johnson, "'May the Force Be with Katie': Pink Media Franchising and the Postfeminist Politics of HerUniverse," Feminist Media Studies 14, no. 6 (2014): 895-911; Mara Wood, "Feminist Icons Wanted: Damsels in Distress Need Not Apply," in A Galaxy Here and Now: Historical and Cultural Readings of Star Wars, ed. Peter W. Lee (Jefferson, NC: McFarland, 2016), 62-83; Carolyn Cocca, Superwomen: Gender, Power, and Representation (Bloomsbury Publishing USA, 2016), 87-120. 


\section{Star Wars and Popular Feminism}

A New Hope arrived in cinemas during what Michelle Citron has described as "a larger mainstreaming of feminism. ${ }^{\text {"10 }}$ Media fans were confident enough about the movement and its tenets to comment on the feminist potential of the products they were consuming and Princess Leia inevitably became part of this discussion. In the second issue of the fanzine Alderaan (1978), one fan wrote: "As a feminist, though I was delighted with Princess Leia, I was disappointed by the dearth of any other major female part-most especially among the pilots of the rebellion. ${ }^{{ }^{\prime 1}}$ In 1983 , Rolling Stone described Leia as "the feminist from the fourth dimension.,"12 Although Leia was recognized as a feminist icon by some, feminist scholars generally ignored her. One reason may be that many influential feminist critics at the time saw little place for feminism in popular culture. Only in the late 199os did this understanding of popular cinema as a "repetitive and formulaic system which reproduces the dominant ideology" begin to shift. ${ }^{13}$

Even then, most feminist readings of Star Wars were negative, in part because they focused on the story arcs of the films' single female leadsfirst Leia and later Padmé Amidala. Margery Hourihan argues that Leia exists mainly to "invest [Luke and friends'] actions with ultimate approval and to mark them as true heroes." ${ }^{\prime 14}$ Diana Dominguez, likewise, writes that, while Leia remains "outspoken and unpunished," she is primarily an enabler for male characters. ${ }^{15}$ Padmé's story, on the other hand, is read as a "disturbingly symbolic" representation of domestic abuse. ${ }^{16}$ Carolyn Cocca devotes a chapter to Leia and Padmé in her book Superwomen, which also includes a discussion of Leia's daughter Jaina Solo from the EU. Despite the many "feminist ideals" these characters embody, Cocca concludes that they remain relatively unchallenging, heteronormative representations. ${ }^{17}$

10 Michelle Citron, "Women's Film Production: Going Mainstream," in Female Spectators: Looking at Film and Television, ed. E. Deidre Pribram (London: Verso, 1988), 56.

11 Jeff Johnston, ed., Alderaan Issue 2, vol. 2 (Toledo, OH: Kzinti Press, 1978), http://oaktrust. library.tamu.edu/handle/1969.1/153131.

12 Carol Caldwell, "Carrie Fisher: A Few Words on Princess Leia, Fame and Feminism," Rolling Stone, 1983 .

13 Mark Jancovich, "Screen Theory," in Approaches to Popular Film, ed. Mark Jancovich and Joanne Hollows (Manchester: Manchester University Press, 1995), 145.

14 Margery Hourihan, Deconstructing the Hero:Literary Theory and Children's Literature (New York: Routledge, 1997), 173.

15 Dominguez, "Feminism and the Force" 112, 120.

16 Domingueez, "Feminism and the Force" 125.

17 Cocca, Superwomen, 87. 
Opinion shifted again in 2015 with the release of The Force Awakens. In popular discussions, Star Wars's feminism was reframed as a progression from Leia (a powerful but solitary role model in the original trilogy) to Rey, who takes up the mantle of Jedi hero that previously belonged exclusively to the male protagonists of the films. This progression was also calculated by the amount of screen time given to female characters and how often they are allowed to speak in the old trilogy as compared to the new. For example, a recent YouTube video cut together all the lines spoken by women other than Princess Leia in the original film trilogy. ${ }^{18}$ The total runtime was just over a minute and there is only a single line from The Empire Strikes Back. From this perspective, Star Wars indeed appears to have come a long way since 1977. The prequel trilogy was certainly more diverse in its casting than the original trilogy, with multiple speaking roles for both women and people of color, and The Force Awakens "has by far the largest number of women, period, in any Star Wars film."

This perspective neglects several important factors, however, not least of which is the transmedial spread of the Star Wars universe. As Dan HasslerForest points out, "our immersion in imaginary story worlds takes place not within, but across, media." ${ }^{20}$ From the earliest days of Star Wars, the story existed beyond the films, spreading across novels, toys, comics, television shows and specials, video games, and more. As Star Wars itself illustrates, a transmedia franchise's feminist politics are much more complex because open-ended storyworlds are always subject to new readings, additions, and alterations.

Star Wars offers a strong example of why increased visibility and accessibility in film do not, by themselves, translate to political change. Joanne Hollows describes how early feminist film criticism tended to focus on images of and for women. ${ }^{21}$ When discussing a popular storyworld's engagement with feminism, however, there are three factors to consider. The first is indeed representational and asks whether a storyworld contains engaging, fully realized female characters. The second is paratextual, pertaining to advertising, merchandise, and reception. Transmedia marketing often

18 Chris Wade, "Women Don't Talk Much in 'Star Wars," YouTube video, 1:23, posted by New York Magazine, December 1, 2015, accessed May 15, 2017, http://www.youtube.com/ watch?v=ODgwL7DJ9dY.

19 Cocca, Superwomen, 115.

20 Dan Hassler-Forest, Science Fiction, Fantasy, and Politics: Transmedia World-Building Beyond Capitalism (London: Rowman \& Littlefield, 2016), 5, original italics.

21 Joanne Hollows, Feminism, Femininity and Popular Culture (Manchester University Press, 2000), 39-40. 
extends beyond the corporate control of Lucasfilm, but it still has a powerful impact on the way the Star Wars brand is consumed and interpreted. Finally, we must also acknowledge industrial and political factors of who is allowed to add to the story and feels entitled to claim it as their own. These factors are often invisible to average consumers and may not even be acknowledged by the storyworld's creators, but they are important if a transmedia franchise like Star Wars is going to inspire sustained, real-world change.

\section{Witches of Dathomir: Representing Feminism in a Galaxy Far, Far Away}

To many fans, Princess Leia was a powerful role model for gender equality, but even she would have been hard-pressed to sustain 40 years of Star Wars fandom by herself. Padmé's character and narrative in the prequel films received mixed responses. Fortunately, despite the tendency of the Star Wars films to focus on a single female hero among a group of men, complex female characters have developed in media across the franchise. The numerous female characters in the texts of the EU (rebranded as Legends in 2014) have formed a large part of the continued draw for female fans. The best-known of these characters is likely Mara Jade, who first appeared in Timothy Zahn's novel Heir to the Empire (1991). ${ }^{22} \mathrm{~A}$ former spy for the Emperor who became a smuggler after his death, Mara initially intends to kill Luke Skywalker, but is instead won over by the New Republic, becomes a Jedi, and eventually marries Luke. Mara was followed by many other popular female EU characters, including Jedi such as Bastila Shan and Jaina Solo, or scientists and soldiers like Jan Ors, Ysanne Isard, and Qwi Xux (the Death Star's lead engineer before Disney's canon reset). The 2003 video game Knights of the Old Republic even features one of the medium's few positive representations of older women and of disability in the form of the player's blind mentor, Kreia. Recently, Anakin's Clone Wars padawan

22 As Tracy "Dunc" Duncan of the long-running fansite ClubJade writes: "Mara is a huge reason I got into the fandom in the first place. And Mara was a large part of the reason I kept reading, which is why I stayed in fandom." Tracy Duncan, "Inside the Star Wars Generation Gap: Why We Still Care about Mara Jade," Club Jade, June 5, 2015, para. 5, http://clubjade.net/?p=64034. Not everyone was as excited about the character, however, and some first-generation fans saw her as "a stereotype of the 'empowered gos woman" meant to tick a demographics box rather than appeal to existing female fans. Shanna Gilkeson, Facebook Messages conversation, November 19, 2016. 
Ahsoka amassed a following that rivalled Mara's. As Cocca has pointed out, however, most of these characters do not really encourage serious discussions of feminism at all because they are "privileged in terms of race, ethnicity, class, ability, and sexuality, and face no discrimination in their seemingly postfeminist and colorblind universes.. ${ }^{23}$ Like Padmé, many of them meet unhappy ends, most commonly for the sake of adding dramatic tension to a male character's story. These trends in the EU material reinforce the disposability and secondary status of women in the franchise overall.

Many factors thus indicate that the Star Wars galaxy is a patriarchal one. There are many female political leaders in Star Wars, but while these individuals often stand against male-dominated systems - the Republic, the Empire, and, in some cases, the Jedi-they rarely succeed in toppling the galaxy's patriarchal customs and politics. Married women take on their male partner's surname and children take the names of their fathers. Luke's surname is Skywalker, not Amidala (or Naberrie), and Kylo Ren's birth name is Ben Solo rather than Ben Organa. ${ }^{24}$ These narrative details obviously reflect our own world more than they do the potential of a science-fictional universe. Most of Star Wars's attempts to imagine a non-patriarchal society can be found in the franchise's non-canonical EU stories. For instance, the Tython Twi'lek community in the massively multiplayer online roleplaying game The Old Republic (2011) is matriarchal, as is the Noghri species from Heir to the Empire. Dave Wolverton's The Courtship of Princess Leia (1994) even brings three separate matriarchies together. The first is the Hapes Consortium, a system of planets populated by pirates but later united and ruled for thousands of years by a matriarchal society led by a ruthless Queen Mother. Much of the story takes place on the planet Dathomir, home to two female-led groups of Force wielders. One of these, the Witches of Dathomir, have allied themselves with the semi-sentient rancor species, who allow the Witches to ride and command them in exchange for special care and protection. The rancors, too, are led by a "herd mother." ${ }^{25}$

Published by Bantam Spectra, Courtship made the New York Times Bestseller list and received largely positive reviews from critics when it was first published in 1995. Following Timothy Zahn's hugely successful Thrawn trilogy (1991-1993), Courtship takes readers back to an earlier point

24 The name Skywalker originally came from Anakin's mother Shmi, but was only passed down because the boy allegedly had no male parent.

25 Dave Wolverton, The Courtship of Princess Leia (New York: Bantam Books, 1995), 240. 


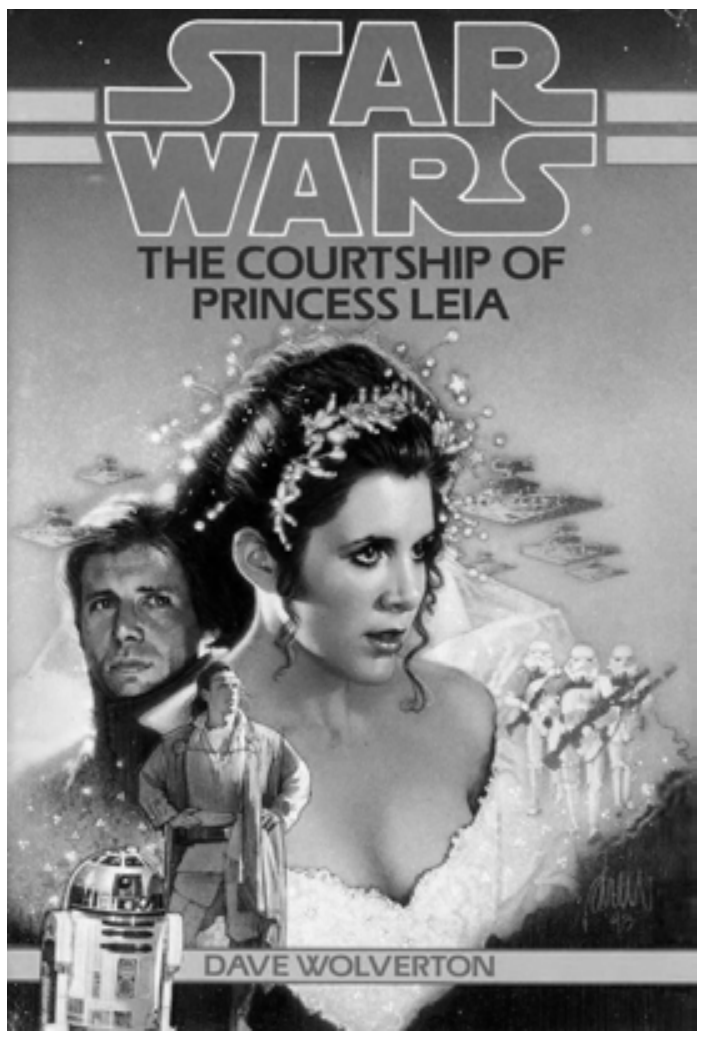

in the Star Wars timeline, telling the story of how Han and Leia developed from quarrelsome lovers into the happy couple depicted throughout the EU. In the novel, the Hapes Consortium offers Leia its wealth and power in the ongoing fight against the remnants of the Empire. Their offer comes with one condition, however: Leia must marry Isolder, the handsome prince whose wife will inherit the Hapan throne. Desperate to stop this marriage, Han kidnaps Leia and takes her to Dathomir, a planet he won in a card game. Luke and Isolder pursue them, only to find themselves embroiled in a conflict with the planet's inhabitants, the warlike descendants of a stranded group of Jedi.

The novel's reception by fans was mixed, with some considering it to be "one of the cheesiest and worst EU novels. ${ }^{{ }^{26} 6}$ But criticism is generally leveled at Courtship's overstuffed plot, melodramatic dialogue, and heavy-handed

26 Scott Rhee, review of The Courtship of Princess Leia, by Dave Wolverton, Goodreads, May 16, 2015, https://www.goodreads.com/review/show/1281835976. 


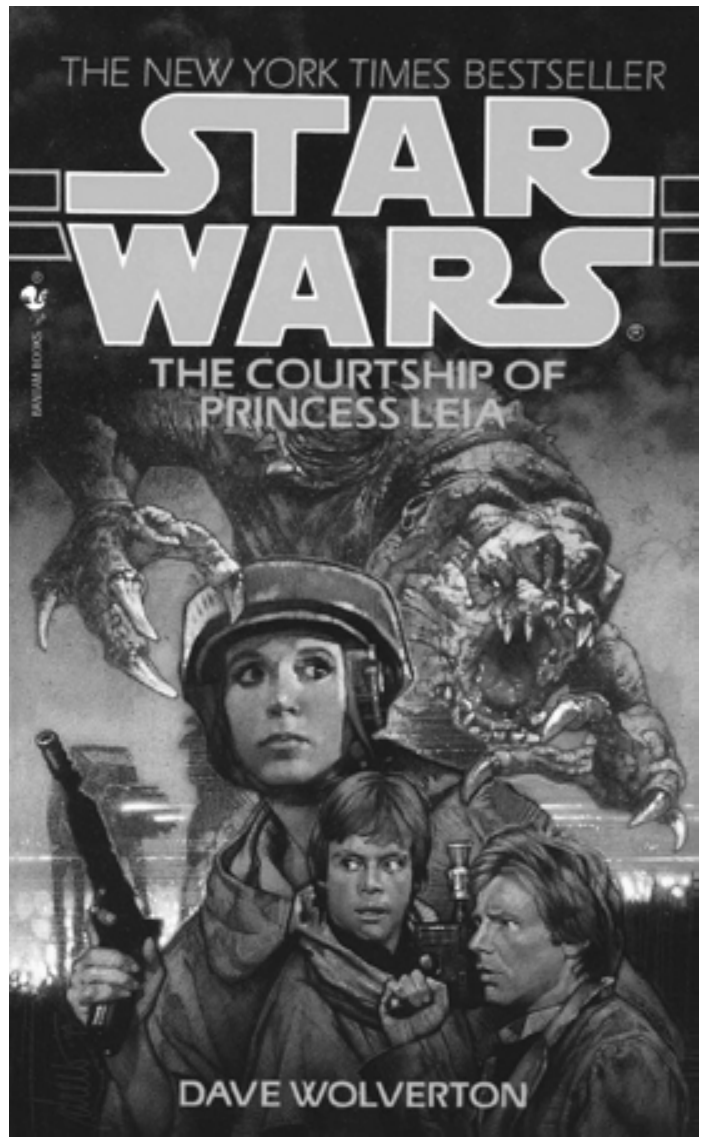

moralizing, rather than its depiction of women. This depiction is positive for the most part-or, at least, as positive as Star Wars depictions of any ruling class, male or female. Women are not evil simply because of their gender. Instead, like the male Force-wielders of the original film trilogy, the Dathomirians are divided by their ideological approach to power: the light-side Witch clans versus the dark-side Nightsisters. The way these matriarchies treat their subordinate male citizens (who lack Force sensitivity) is likewise divided by ideology rather than gender. The Witches have a complex gendered hierarchy, while the Nightsisters seem only to use men as slaves and breeders.

In a 2016 interview, Wolverton argued that his idea for Courtship's matriarchal societies came about because "there really aren't a lot of powerful female characters in that universe" and he wanted to show "a 
strongly feminist society where women were in control. ${ }^{27}$ Although it features matriarchal societies and strong female characters, Courtship is ultimately unconvincing as a feminist narrative. Luke, Han, and Isolder are the story's real heroes. The Witches only defeat the Nightsisters and the Imperial Warlord Zsinj with Luke's help, Han wins his battle for Leia's affections, and Isolder stands up to his mother, the Queen of the Hapes Consortium, by choosing to marry for love rather than political advantage. While the novel also features powerful, positive depictions of older women, the Witches' skimpy tunics and exotic headdresses harken back to the sexualized Amazonian warriors of 1950 s science fiction.

"Feminism" thus becomes synonymous with "female-dominated," and, like other readings of strong women in Star Wars, "plays to fears that feminism means not equality, but man-hating female superiority. ${ }^{28}$ As many fans at the time protested, Courtship also valorizes Han's abduction and subsequent seduction of Leia, perpetuating the dangerous myth that women must be coerced into sexual consent. ${ }^{29}$ Therefore, in spite of its gender-progressive ambitions, the novel consistently exoticizes and objectifies its female characters and caricatures the feminism it claims to support as a result. Though it opens up a space for feminist discourse, Courtship also serves as a useful illustration of the way strong female characters and stereotypically feminine genres (like romance) can still fail the most basic feminist expectations on numerous levels.

\section{Store Wars: Feminist Merchandising and the Gender Gap}

While Star Wars's representations of a matriarchal society are ideologically ambiguous, its gendered approach to merchandising has influenced the storyworld's engagement with feminists and feminism most negatively in recent years. The idea that gendered toys can communicate certain heteronormative ideals to their young consumers is a familiar one. As Jonathan Gray has argued, both marketing and the way consumers interact with

27 “Bombad Radio \#51:With Author Dave Wolverton/Farland,"YouTube video, 1:06:48, posted by Trail Makers, May 1, 2016, accessed May 15, 2017, https://www.youtube.com/watch?v=Jdb_RAJtop8. 28 Cocca, Superwomen, 102.

29 See Doug McCausland, "Lit Exclusive: Dave Wolverton Addresses Fan Criticisms of The Courtship of Princess Leia, \& MORE," Jedi Council Forums, November 17, 2014, accessed May 15, 2017, http://boards.theforce.net/threads/lit-exclusive-dave-wolverton-addresses-fan-criticismsof-the-courtship-of-princess-leia-more.50024454/, which includes Wolverton's defense of this plot point. 
licensed products such as toys create a message about the franchise. Such textual supplements, or paratexts, "tell us what to expect, and in doing so, they shape the reading strategies that we will take with us 'into' the text. ${ }^{\prime 3^{0}}$ In her doctoral dissertation on the gendering of toy packaging in the twentieth century, Elizabeth Sweet describes toys as "material objects that embody the prevailing ideas of the society in which they are made [...] [that] also act as an important tool for the intergenerational transmission of cultural norms and beliefs. ${ }^{{ }_{31}}$ When toys or other children's merchandise are explicitly gendered as "for boys" or "for girls," they transmit messages about the types of play and stories with which children should engage. Star Wars merchandise is no different.

On January 4, 2016, for example, just a few weeks after the release of The Force Awakens, Carrie Goldman tweeted a picture of a letter written by her eight-year-old daughter. It read:

Dear Hasbro,

How could you leave out Rey!? She belongs in starwars [sic] monopoly and all the other starwars games! Without her, THERE IS NO FORCE AWAKENS! It awakens in her! And without her, the bad guys would have won! Besides, boys and girls need to see women can be as strong as men! Girls matter! Boy or girl, who cares? We are equal, all of us!

Sincerely,

Annie Rose (age 8) $)^{32}$

The absence of Rey merchandise was read as an anti-feminist statement and an inaccurate reflection of the film's own feminist sensibility. Annie Rose's letter sparked a flurry of debate around the \#WheresRey hashtag, intended to pressure toy companies into releasing more Rey toys, and more Star Wars merchandise "for girls" in general. ${ }^{33}$

30 Gray, Show Sold Separately, 26.

31 Elizabeth V. Sweet, "Boy Builders and Pink Princesses: Gender, Toys, and Inequality over the Twentieth Century” (PhD diss., University of California, Davis, 2013), 5, http://search.proquest. com/docview/1517101640.

32 Carrie Goldman (@CarrieGoldman), Twitter post, January 4, 2016, 5:17p.m., https://twitter. com/CarrieMGoldman/status/683819496759537664, original emphasis.

33 A few days later, Hasbro announced that they would be releasing a new version of Monopoly that included the character. See Michelle R. Smith, "Star Wars' Monopoly Will Now Include Rey after an 8-Year-Old Wrote to Hasbro Telling Them 'Girls 
Fans were quick to point out that this gap in the market was not new, nor had it gone unnoticed in the past. In the wake of another hashtag campaign, \#WeWantLeia, as well as a "furious" father's complaint about Hasbro's Black Series Slave Leia (complete with neck chain) in his local toy aisle, ${ }^{34}$ a mother's 1983 letter to an Arizona magazine made the rounds of the internet. "Why is it that in all the mounds of Star Wars figures in all the stores in town there's not a single Princess Leia to be found?" she asked..$^{35}$ One of the online magazines that circulated the letter framed the complaint as one in a long history of exclusion "that crops up regularly, in other words, because girls have always loved this franchise." ${ }^{36}$

While this comparison between similar forms of outcry in 1983 and 2015 is provocative, it glosses over several important developments in the toy industry. For one, gender stereotyping in children's toys has become far more pronounced since the late 1990s: “even when gender coding isn't explicitly reinforced by obvious signage in stores or different pages on the web, the pervasive color coding of toys and the use of gender-stereotypical themes makes gender distinctions among toys impossible to avoid." ${ }^{37}$ The subsequent trend of basing children's programming on toy lines, inspired in part by the phenomenal success of Kenner's Star Wars action figures, prioritized boys over girls as consumers well into the 1990s. As Gray points out, Kenner's color scheme and "framing of Star Wars as battle- and conflictdriven [...] hypermasculinized the toys. [...] Ads then carried this further, as did the packaging itself, which inevitably depicted young boys at play, not young girls." ${ }^{8}$ Indeed, toy companies have been "quite explicit about

Matter,'” Business Insider, January 8, 2016, accessed May 15, 2017, http://uk.businessinsider.com/ ap-star-wars-monopoly-to-include-rey-after-8-year-olds-note-2016-1.

34 Chris O'Connell, "Star Wars Action Figure Has Parents Furious," Fox 29, July 13, 2015, http:// www.fox29.com/news/2029186-story."That's pretty inappropriate," he allegedly objected. "I got two daughters I don't need seeing that crap."

35 Susan Mills, "Where Are the Princess Leia Dolls?," The Courier, December 9, 1983, sec. Letters, 5 A.

$3^{6}$ Kelly Faircloth, "Parents Have Been Requesting Star Wars Toys for Their Daughters For Decades," Jezebel, November 13, 2015, para. 5, http://pictorial.jezebel.com/parents-have-been -requesting-star-wars-for-their-daught-1742316633.

37 Sweet, "Boy Builders and Pink Princesses," 1.

38 Gray, Show Sold Separately, 186. It's worth noting that not all of Kenner's toy products share this same set of representational biases. Its R2-D2 and Jawa "Bop Bags," for example, feature both a young boy and a young girl on the packaging. The 1977 Early Bird Certificate Package commercials also featured a boy and girl playing with action figures together, and one of the three children in the Escape from Death Star board game commercial is female. When girls appear in these ads, they are often shown playing with the female-gendered toys in the advertised playsets, but otherwise they participate equally. 
their strategy of segmenting the child market along gender lines in order to sell more products." ${ }^{39}$

In the days of the original trilogy, however, toys were not nearly as heavily gender-marketed as they are today. Additionally, though most of the original Star Wars merchandise was aimed at children, Star Wars was everywhere by 1983 , not just in children's products. Chris Taylor describes the period as "more obsessed with the saga than ever, awash in Return of the Jedi-themed Pepperidge Farm cookies, AT\&T Darth Vader phones, and Coca-Cola Star Wars collectible glasses. Kids donned their Return of the Jedi roller skates to visit the Jedi Adventure Center at their local mall. ${ }^{40}$ These products are not as clearly gender-coded as dolls or action figures, though some were certainly marked by the color schemes Gray describes.

But Annie Rose's point about Rey's centrality to the plot of The Force Awakens complicates the discussion of toy merchandising. In this case, a character who is central to the film's plot is excluded from merchandise, allegedly because of her gender. With Leia, the situation is usually quite different. In its infamous "empty box" campaign of Christmas 1977, Kenner sold an Early Bird Certificate Package containing a Star Wars Space Club membership card, stickers, a set of cardboard characters, and a postcard that could be redeemed for an actual toy. ${ }^{41}$ In the set of four action figures that could be claimed with these vouchers from the spring of 1978 , Leia was included alongside Luke, Chewbacca, and R2-D2, suggesting her importance to the story. ${ }^{42}$ She was also featured prominently on general merchandise like lunchboxes and T-shirts, and, in one instance, a set of Underoos. ${ }^{43}$ While the mother in 1983 may not have been able to find Leia in her local toy store (perhaps due to demand or distribution issues), Leia was certainly out there.

Another concern with contemporary Star Wars merchandising involves the industry's own attempts at "feminist" marketing. Derek Johnson writes

39 Sweet, "Boy Builders and Pink Princesses," 2.

40 Chris Taylor, How Star Wars Conquered the Universe: The Past, Present, and Future of a Multibillion Dollar Franchise (New York: Basic Books, 2014), 271.

41 See Ryan Lambie, "Star Wars: How an Empty Box Became a Must-Have Item in 1977," Den of Geek, January 11, 2016, http://www.denofgeek.com/go/38416.

42 Though she was never as popular as the film's male leads, Kenner/Hasbro made 44 Leia figures between 1978 and 2012. Compare this to Luke Skywalker, the most frequently reproduced figure, who had 89 versions in the same period. Including Leia, Hasbro has released 95 different female characters in total from across the franchise, many of which have multiple versions and releases (Padmé comes in 26 varieties). Taylor, How Star Wars Conquered the Universe, 206.

43 Jason Bailey, “The Most Bizarre Tie-In Merchandise from '8os Movie Classics," Flavorwire, February 27, 2013, http://flavorwire.com/373862/the-most-bizarre-tie-in-merchandise -from-8os-movie-classics. 
about various forms of "pink media franchising" in Star Wars, arguing that "the historical organization, production, and marketing of the Star Wars franchise has relied upon logics of gender difference that suggest unequal industry interest in reaching boys versus girls, and men versus women." ${ }^{\text {"44 }}$ In other words, he suggests, these marketing paratexts have "cast Star Wars as almost always for boys yet sometimes for girls." ${ }^{25}$ This perception has received the strongest outcry from feminist fans, but, as Suzanne Scott has noted, how the franchise appeals to girls is just as significant as whether it does at all. In her article on the gender politics of media paratexts, Scott argues that "when merchandise aimed at female fans does appear, these paratexts routinely function as heterosexist attempts to hail them as postfeminist consumer subjects, rather than acknowledging them as a part of the franchise's preexisting fan demographic. ${ }^{246}$

Johnson, likewise, discusses the way twenty-first-century affirmations of female Star Wars fans are often synonymous with their re-absorption into a heteronormative, postfeminist princess culture. Specifically, he takes the examples of Katie Goldman, a girl who was teased at school for her Star Wars water bottle, and of Her Universe, an online fashion and accessories company managed by Clone Wars voice actress Ashley Eckstein. Although female fans are celebrated in both examples as "different," Johnson argues that "both industry and vernacular media cultures repositioned these figures in relation to beauty, princesses, heteronormative romance, and other postfeminist (but traditionally feminine) ideological frames. ${ }^{37}$

Another part of the problem, therefore, is that merchandise is generally reserved for the "official" portions of the franchise. The EU stories, which still proportionally feature the largest group of female Star Wars characters, are typically ignored. Likewise, fan fiction-as an unlicensed activity that draws disproportionately large numbers of female fans and that represents a diversity that official products have never come close to matching-is unrepresented in official merchandise. However, unsanctioned play can still have an outsized impact on mainstream readings of Star Wars, especially on perceptions of its engagement with feminist politics.

44 Johnson, "May the Force Be with Katie," 899.

45 Johnson, "May the Force Be with Katie," 900.

46 Suzanne Scott, “\#Wheresrey?: Toys, Spoilers, and the Gender Politics of Franchise Paratexts,"

Critical Studies in Media Communication, 34, no. 2 (2017): 138-147.

47 Johnson, "May the Force Be with Katie," 895. 


\section{A Woman's Place is in the Resistance: Rogue Readings and Feminist Activism}

Historically, critics have not categorized Star Wars fandom as politically progressive. As Sarah Calise argues through an analysis of fanzines, "The Star Wars fandom, in particular, mirrored American society's views on gender and sexual identities in the 1970s and 1980s," though it became somewhat more welcoming as it developed into the $1990 \mathrm{os}$ and onto the internet. ${ }^{48}$ Recent critical work has described Leia as the first feminist action hero of a new generation that came to feature outspoken and physically capable characters such as Ellen Ripley and Sarah Connor. ${ }^{49}$ This characterization is undoubtedly owed in large part to Carrie Fisher, herself an outspoken feminist, who remained vocal about her role as Leia-and the sexism levelled at her and her character-until her death in 2016. In a 1983 Rolling Stone interview (the same edition in which Leia frolics on the cover in her slave-girl bikini), Fisher dismissed descriptions of Leia as a "space bitch"50 and discussed the challenges of playing a strong female character:

You can play Leia as capable, independent, sensible, a soldier, a fighter, a woman in control - control being, of course, a lesser word than master. But you can portray a woman who's a master and get through all the female prejudice if you have her travel in time, if you add a magical quality, if you're dealing in fairy-tale terms. People need these biggerthan-life projections..$^{51}$

This message of empowerment through fantasy is one that feminists (and female fans) took to heart in the ensuing years.

It may come as no surprise, therefore, that many also took their fandom into the realm of direct political action. Fisher's death on December 27, 2016 closely followed the contentious election of Donald Trump and her name and likeness as Leia became a rallying cry among women in the subsequent

48 Sarah E. Calise, "A Force to Be Reckoned With: Women, Star Wars, and Controlling Cultural Production, 1977-1990," Independent Research (Albert Gore Research Center, May 2016), 7, https:// sarahcalise.files.wordpress.com/2016/o1/a-force-to-be-reckoned-with.pdf.

49 See Gladys L. Knight, Female Action Heroes: A Guide to Women in Comics, Video Games, Film, and Television (Santa Barbara, CA: ABC-CLIO, 2010); Caroline Heldman, et al., "Hot, Black Leather, Whip': The (De)evolution of Female Protagonists in Action Cinema, 1960-2014," Sexualization, Media, \& Society 2, no. 2 (April 22, 2016): 1-19; Cocca, Superwomen.

50 Caldwell, "Carrie Fisher," para. 2.

$5^{1}$ Caldwell, "Carrie Fisher," para. 11, original emphasis. 


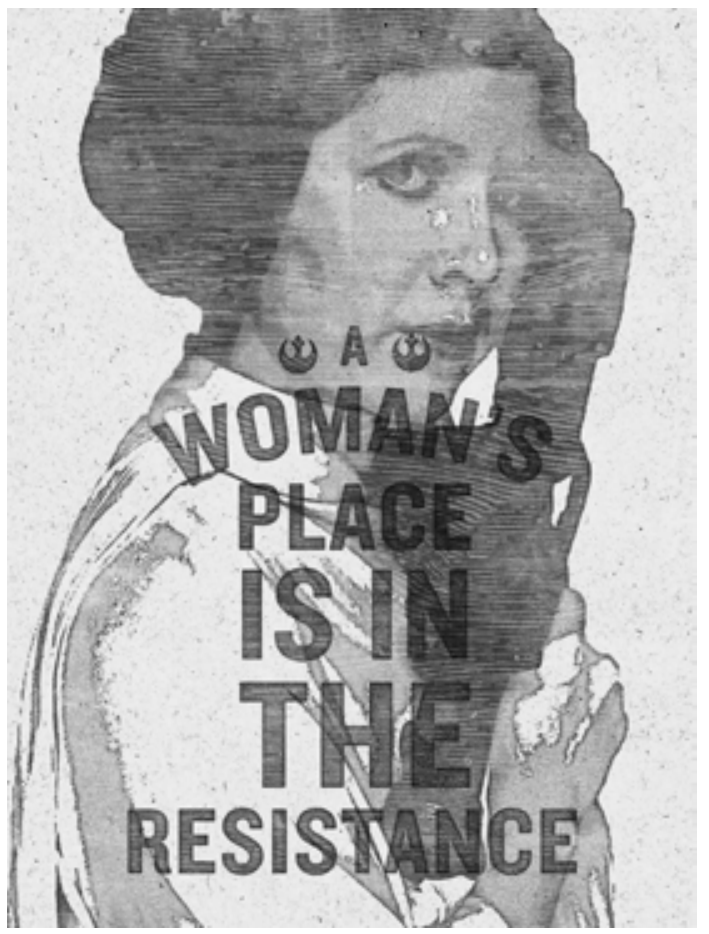

months. The unprecedented Women's March on 21 January 2017 protested Trump's inauguration and sought to mobilize support for the preservation of women's rights. Posters of Princess Leia received substantial media coverage during the event, and one particularly popular sign, designed by Hayley Gilmore, read: "A Woman's Place is in the Resistance." ${ }^{22}$ Still other images portrayed Trump as Jabba the Hutt, and dozens of "Jabba the Trump" memes and cartoons, some featuring a "Huttslayer" Leia character, were circulated online. Both sets of images situated the Trump administration within the Star Wars universe as an evil, anti-feminist force to be vanquished, and Leia as a feminist role model leading the vanguard. ${ }^{53}$

52 Others proclaimed "We Are the Resistance" and "Rebel Against Hate" beside an image of Leia, or depicted her as the 1940 s icon Rosie the Riveter. Angela Watercutter, "Princess Leia Gave the Women's March a New Hope," WIRED Magazine, January 23, 2017, https://www.wired. com/2017/o1/princess-leia-womens-march/.

53 Fisher's advocacy of the movement as Princess Leia lends this reading authority, if not the official Lucasfilm stamp of endorsement. Though many key Star Wars figures (including Mark Hamill, Daisy Ridley, and Lupita Nyong'o) came out strongly on social media in support of the 
In these fans' reading of Leia, her position as a lone woman among men became a positive point of identification rather than a negative example of Hollywood gender inequality. Like themselves or like women they knew, Leia had faced numerous struggles and injustices in a patriarchal society, but nevertheless persisted. In this sense, Star Wars is made feminist by the fans, through public forms of "fannish play," even when the franchise's own message is ambiguous and often confusing.

In conclusion: Star Wars has not become fundamentally more or less feminist over the past 40 years. Instead, its engagement with feminist discourse has constantly shifted, shaped by the radical changes that both the transmedia franchise and the political movement have undergone. One thing that seems increasingly clear is that Star Wars tends to follow mainstream politics rather than revolutionary ones. Fans, however, have used their engagement with Star Wars to expand the boundaries of the storyworld and continually transform it into something with real-world impact. Despite the new Lucasfilm Story Group's efforts to ensure "all Star Wars stories tell the same story," ${ }^{44}$ ultimately it is not Star Wars's representation of women or its own feminist agenda that matters most, but rather how these representations and aims are continually negotiated and reinterpreted by fans, creators, licensees, and feminists around the world.

Women's March—and its use of Leia-Disney/Lucasfilm predictably refrained from mentioning either on its official channels.

54 Germain Lussier, "How The Lucasfilm Story Group Does Star Wars Canon," Slashfilm, April 20, 2015, para. 1, http://www.slashfilm.com/lucasfilm-story-group-star-wars-canon/. 